\title{
EVOLUTION IN CLOSELY ADJACENT PLANT POPULATIONS \\ V. EVOLUTION OF SELF-FERTILITY
}

\author{
JANIS ANTONOVICS* \\ Department of Agricultural Botany, University College \\ of North Wales, Bangor
}

Received 26.vii.67

\section{INTRODUCTION}

THE role of breeding systems in plant evolution has been frequently discussed. On the basis of simple theory, inbreeding should lead to homozygosity and loss of variability, whereas outbreeding should conserve this variability. Inbreeding is generally regarded as a retrogressive step which eventually leads to extinction.

However, it has been shown recently that the amount of variability present in inbreeding species has been underestimated (Imam and Allard, 1965; Allard, 1965). Moreover, species showing inbreeding are numerous and often very successful.

Rather than inquire why self-fertility has developed faut de mieux, it is therefore pertinent to look for its direct adaptive value.

(i) Certainty of fertilisation. Several species are known to self-pollinate under conditions unfavourable to cross-pollination (Rick, 1950; Stebbins, 1957; Lloyd, 1965).

(ii) Establishment after long-distance dispersal. The absence of other plants after establishment following long-distance dispersal means that only self-fertile individuals can perpetuate themselves (Baker, 1955; Stebbins, 1957; Bannister, 1965).

(iii) Density of plants. If the plants are widely scattered and crosspollination is difficult self-fertility may be advantageous (Baker, 1953).

(iv) Earliness of flowering. Self-fertility in the early flowering types would be advantageous because there may be few other plants in flower to pollinate them (Moore and Lewis, 1965).

(v) Exposure of recessives. Useful recessive genes will be unmasked more easily by inbreeding. Moore and Lewis (1965) describe a derived self-fertile population of Clarkia which has white petals (recessive).

(vi) Uniformity. It may be advantageous for the descendants of an initial coloniser to resemble each other and the coloniser as closely as possible. This can be achieved by self-fertility and homozygosity.

(vii) Prevention of gene flow. Where distinctive adapted populations of a species are adjacent, crossing with extraneous pollen may lead to a dilution of the adaptive characters. Selfing would avoid this (Baker, 1959).

There is therefore evidence for a wide range of factors which might be important in putting self-fertilisation at a premium. However, the processes

* Present address: Department of Biology, The University, Stirling. 
of selection producing self-fertilisation have been little examined: most of the evidence is circumstantial and comes from comparisons between species.

Beddows (1931) and Jenkin (1931) working on grasses, Julen (1948) and Davies and Young (1966) on legumes, and Thompson and Taylor (1966) on brassicas have shown that there is considerable variability in selfcompatibility of natural and semi-natural populations. In some instances, highly self-fertile plants also have highly self-fertile progenies (Jenkin, 1931; Thomas, 1955; Thompson and Taylor, 1966) while Rowlands (1960) showed in Vicia that self-fertility was clearly inherited. Breese (1959) changed the self-fertility of Nicotiana by selection for different floral morphology. Selection for self-fertility in natural populations should therefore be possible (see also Rowlands, 1961).

In previous papers in this series, situations have been described where there is sharp differentiation between populations only a few metres apart. The situation at the boundary of metal mines and normal pastures seemed ideal for examining the evolution of breeding systems: fairly wide seed dispersal is sometimes necessary to colonise mine soil, mine populations flower earlier, there is a wide range of plant density on different mines, and there is considerable gene flow between the populations.

The study was divided into three parts: the establishment of differences in self-fertility of plants from adjacent populations, an examination of differences in self-fertility of various metal tolerant populations, and a computer simulation of the possible evolutionary processes.

\section{Self-Fertility of adjacent populations}

(i) Methods

To assess whether adjacent populations differed in their self-fertility, plants were collected as single tillers from sites along transects across two mine boundaries. Agrostis tenuis was collected from a copper mine at Drws-y-Coed, Caernarvonshire, and Anthoxanthum odoratum from a lead and zinc mine at Trelogan, Flintshire. These transects have been described by McNeilly (1967) and McNeilly and Antonovics (1967). Both cross a sharp boundary between mine and pasture and heavy metal tolerance changes abruptly at the boundary.

Self-fertility was estimated by enclosing about five inflorescences of one genotype inside a glassine pollination bag and counting seed set. Seed viability was confirmed by germination tests.

\section{(a) Population differences}

(ii) Results

The self-fertility of tolerant populations is far in excess of the self-fertility of the adjacent non-tolerant populations (figs. 1 and 2) in both Agrostis and Anthoxanthum. The pattern of distribution of self-fertility within the populations shows that while all the individuals in the non-tolerant populations have low self-fertility, the tolerant population contains individuals with very high self-fertility. Equally startling is the sharp difference at the population boundary; it is another example of population differentiation over short distances. Even for two species and two contrasting mines, the pattern is very similar. The difference between tolerant and non-tolerant plants in their seed set on selfing cannot be due to differential sensitivity to 
(a) Anthoxanthum from Trelogan

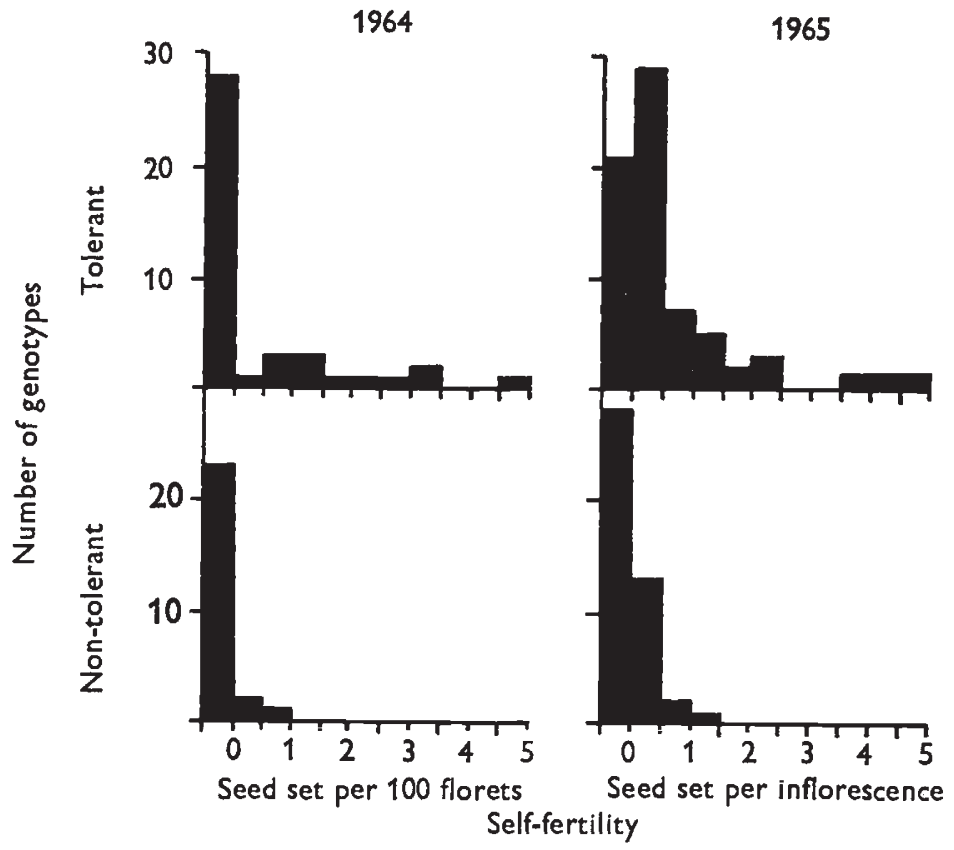

(b) Agrostis from Drws-y-Coed
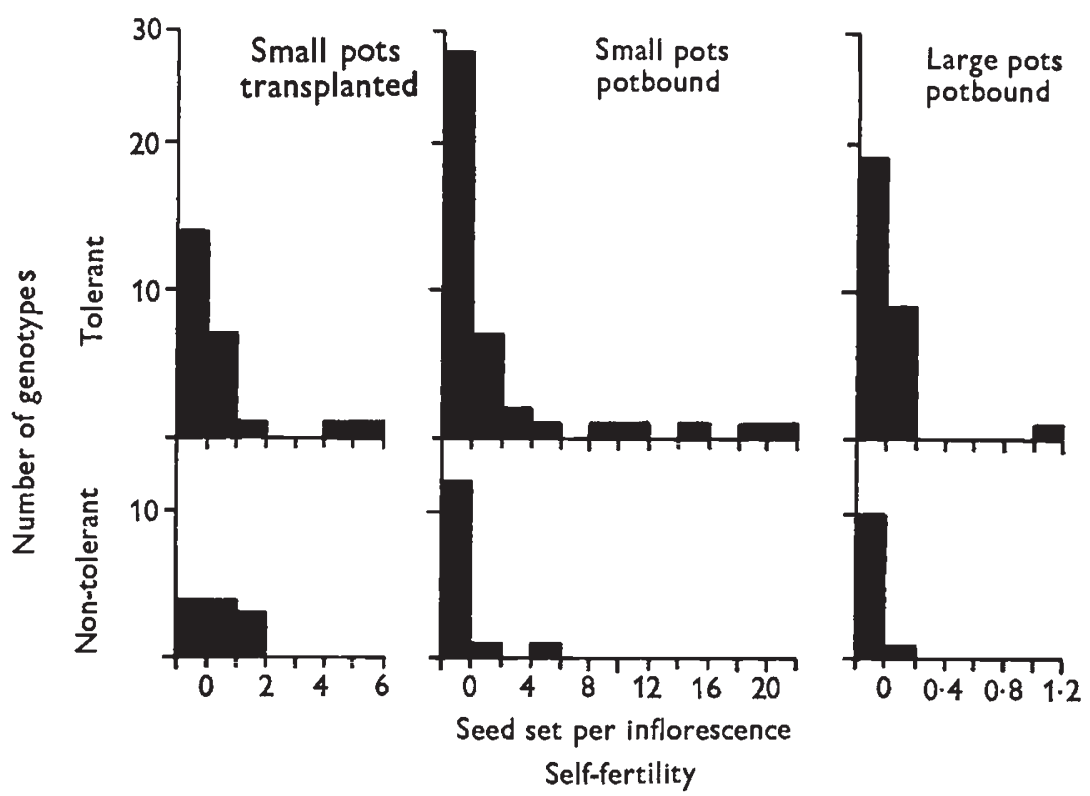

FIG. 1,-Distribution of self-fertility of genotypes in tolerant and non-tolerant populations. 
bagging since there are no significant differences between tolerant and non-tolerant plants when crosses are made between genotypes within each population (McNeilly and Antonovics, 1967; Antonovics, 1966).

(a) Anthoxanthum from Trelogan

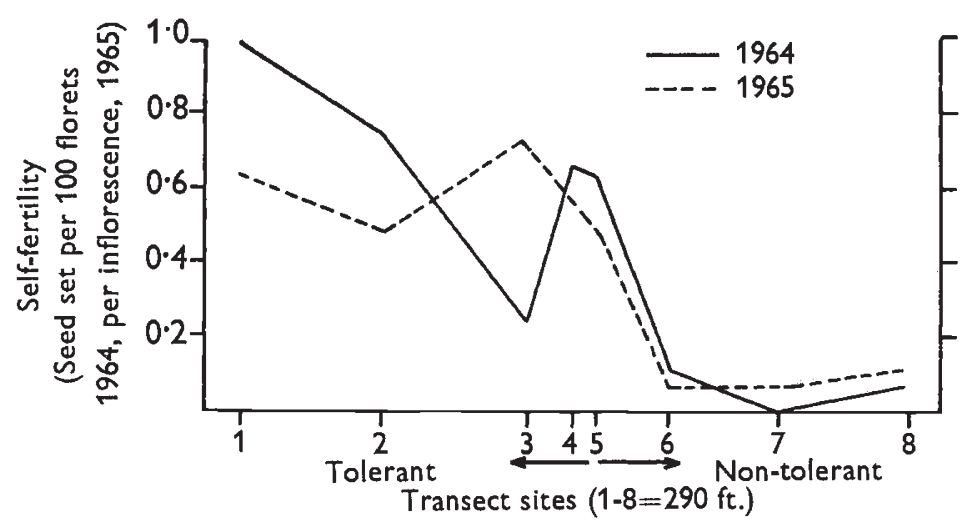

(b) Agrostis from Drws-y-Coed

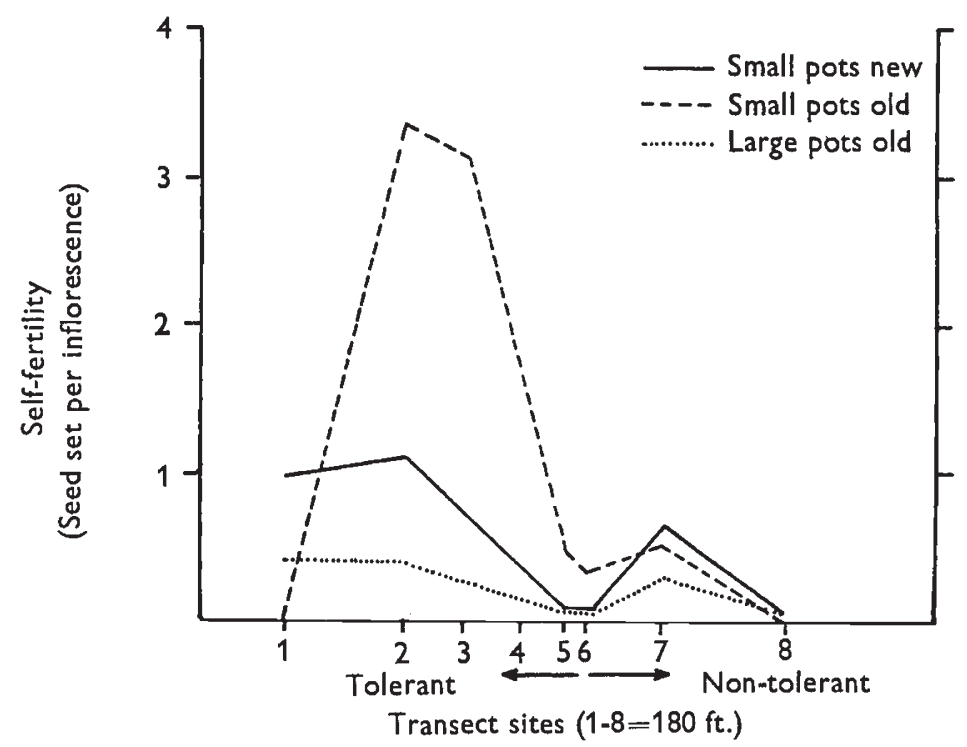

FIG. 2.-Mean self-fertility of genotypes sampled from sites across the mine boundaries.

\section{(b) Genotype differences}

In Anthoxanthum in 1965 replicate selfs were made. From the analysis of variance (table $1 a$ ) the relative genetic contribution to the overall variance in self-fertility (broad sense heritability) could be estimated and gave a value of $66 \cdot 4$ per cent. 
In Agrostis, collected from a series of mines in Cardiganshire (see Section 2), a similar calculation (table $1 b$ ) gave a value of $59 \cdot 1$ per cent.

Moreover, in Anthoxanthum the degree of self-fertility is correlated between genotypes over years within the tolerant population (fig. 3a), and in Agrostis there is a significant correlation between the self-fertility of genotypes grown under different preculture conditions (fig. $3 c$ ).

These results therefore point to a strong genetic component for this character.

TABLE 1

Analysis of variance on self-fertility in different tolerant genotypes

\begin{tabular}{|c|c|c|c|c|c|}
\hline \multicolumn{6}{|c|}{ (a) Anthoxanthum (Trelogan) } \\
\hline Source & $\begin{array}{l}\text { Sums of } \\
\text { squares }\end{array}$ & d.f. & $\begin{array}{l}\text { Mean } \\
\text { square }\end{array}$ & F & Expectation \\
\hline $\begin{array}{l}\text { Total } \\
\text { Genotypes } \\
\text { Error }\end{array}$ & $\begin{array}{l}875 \cdot 46 \\
658 \cdot 23 \\
217 \cdot 23\end{array}$ & $\begin{array}{r}178 \\
48 \\
130\end{array}$ & $\begin{array}{r}-\overline{13 \cdot 71} \\
1.67\end{array}$ & $\begin{array}{c}\overline{-} \\
8 \cdot 21^{* * *} \\
-\end{array}$ & $\begin{array}{c}3.64 \bar{\sigma}_{g}{ }^{2}+\sigma_{e}{ }^{2} \\
\sigma_{e}{ }^{2}\end{array}$ \\
\hline \multicolumn{6}{|c|}{ (b) Agrostis (Cardiganshire) } \\
\hline Source & $\begin{array}{l}\text { Sums of } \\
\text { squares }\end{array}$ & d.f. & $\begin{array}{l}\text { Mean } \\
\text { square }\end{array}$ & F & Expectation \\
\hline Total & $7908 \cdot 0$ & 81 & - & - & - \\
\hline Genotypes & $6260 \cdot 3$ & 40 & $1565 \cdot 1$ & $3 \cdot 89 * * *$ & $2 \sigma_{g}^{2}+\sigma_{e}^{2}$ \\
\hline Error & $1647 \cdot 7$ & 41 & 401.9 & - & $\sigma_{e}^{2}$ \\
\hline
\end{tabular}

\section{(c) Inheritance}

Seed produced by selfing was grown up and the self-fertility of the mature plants tested. In Anthoxanthum a significant parent-offspring regression was obtained (fig. $3 b$ ). This regression is only an approximate estimate of heritability since the offspring are products of selfing and not crossing. The results for Agrostis were less clear cut because many of the plants ( 43 plants, 14 families) failed to set seed. But plants from one mine population set seed and showed a significant parent offspring regression (fig. $3 d$ ) when an extreme individual which produced 60 seeds per inflorescence and which came from the highest selfing parent was removed from the calculation. The regression had a slope greater than unity suggesting that progeny produced by selfing have an improved ability to self. It is not clear why Agrostis from other mines produced no seed. It could have been a direct consequence of inbreeding depression, but equally it could have been because the plants were planted rather late (January).

\section{(d) Inbreeding depression}

The morphological characters, height, number of vegetative tillers, number of reproductive tillers, and within plant variation in flag-leaf length were measured in the course of a spaced plant trial (Antonovics, 1966). No significant relationship between these characters and selfing was found, so providing no evidence that plants that have a higher self-fertility are in any way less "fit" than self-sterile individuals. However, the plants were grown as spaced individuals, and were adults collected from the mine and therefore already the result of selection. 


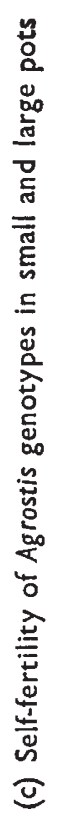
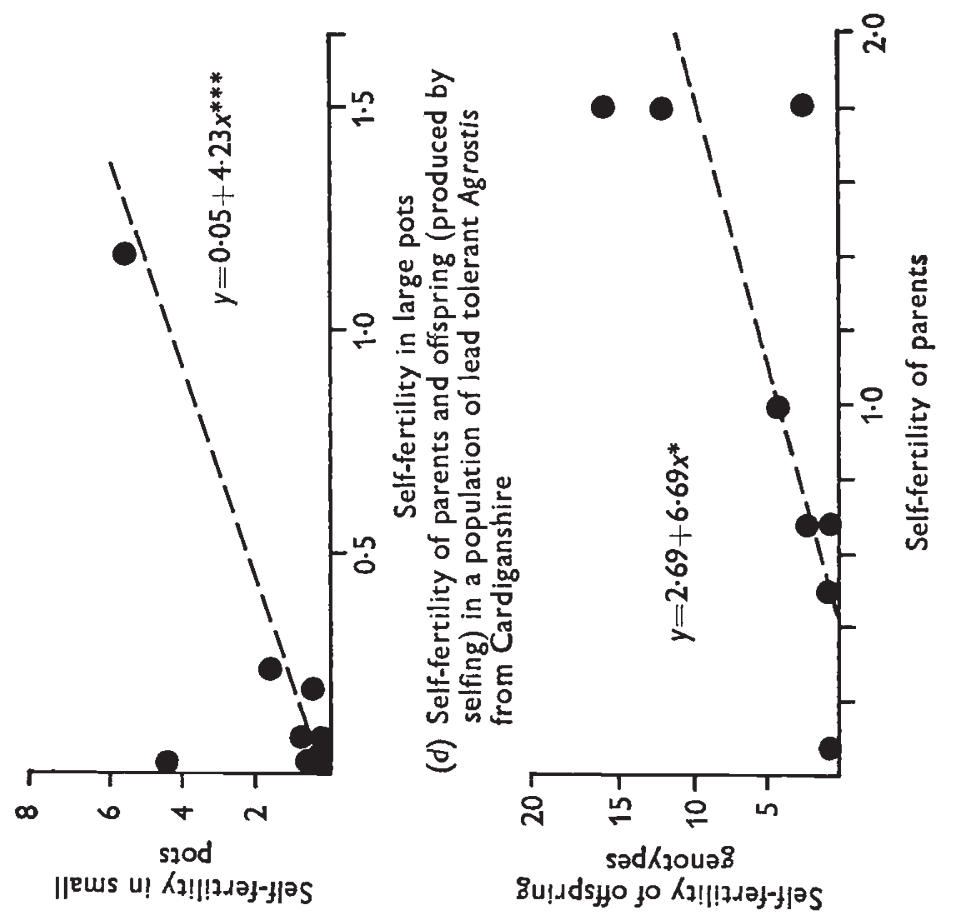

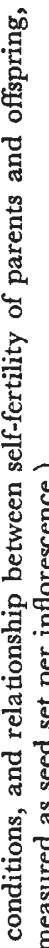

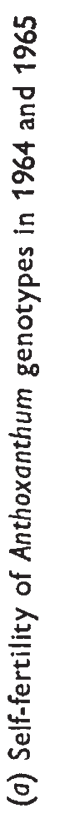
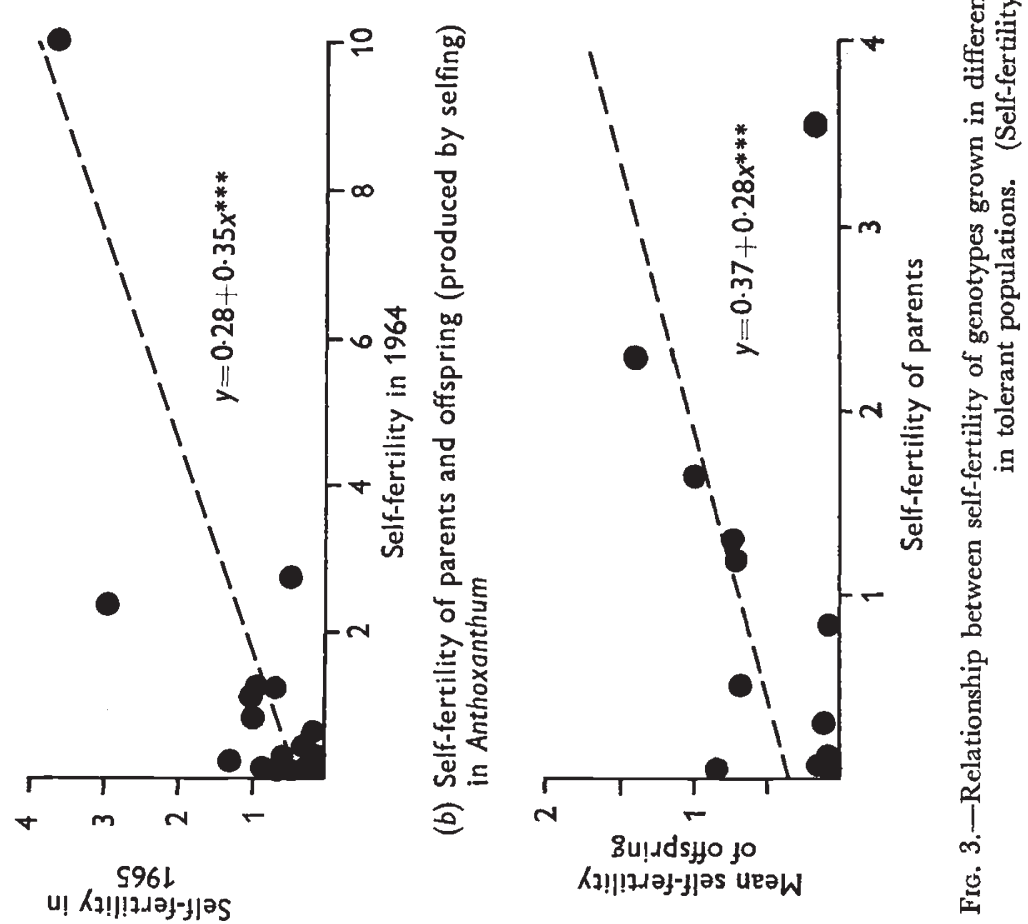
The performance of individuals produced by selfing was therefore studied in competition with those produced by crossing, using tolerant material. Seedlings from artificial crosses and selfs were grown in $50: 50$ mixtures and in pure stands after the method of De Wit (1960), in sterilised loam in an unheated greenhouse. Twenty-four seedlings per box were planted at 2-inch spacing, with a guard row and two replicates. Pure

\section{Dry weight (Total of 24 plants)}

Tiller number (Total of 24 plants)

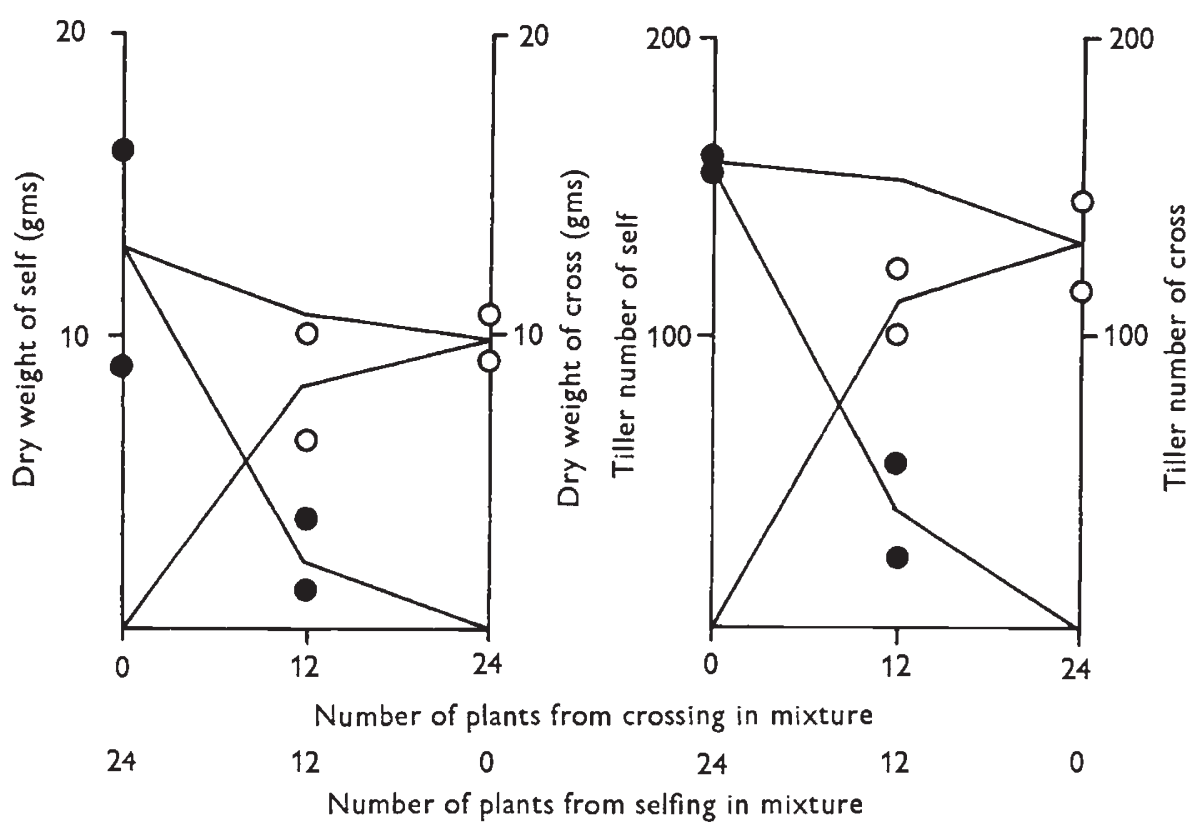

FIG. 4.-Replacement series graphs showing yield of progeny of tolerant selfs and tolerant crosses in mixtures and pure stands, after 19 months.

stands at half-density were included so that percentage reduction by a competitor ("selection pressure" due to the other type) could be assessed (Seaton and Antonovics, 1967).

It is seen from the Replacement Series Graphs (fig. 4) that in pure stands the progeny produced by selfing perform about the same as those produced by crossing, but in mixtures the tolerant crosses yield relatively more than tolerant selfs. The percentage reduction from pure stands at half density (table 2) confirms these results. The selection pressures are strongest against the selfed types and increase with successive harvests.

\section{(iii) Conclusion}

The greater self-fertility of tolerant populations is notable in view of the rarity with which differences in breeding systems have been demonstrated within a species. The sharpness of the change at the boundary is also 
important. The character is clearly inherited and results in a certain amount of inbreeding depression. The evidence implies that selective processes are at work.

\section{TABLE 2}

Selection pressure in mixtures against plants produced by selfing and plants produced by crossing

\begin{tabular}{|c|c|c|c|c|}
\hline & \multicolumn{3}{|c|}{$\begin{array}{c}\text { Harvest Date } \\
\text { (months after sowing) }\end{array}$} \\
\hline & & 7 & 11 & 19 \\
\hline \multirow{2}{*}{ Tiller Number } & (Selfing & 37 & 52 & 74 \\
\hline & Crossing & 38 & 34 & 31 \\
\hline \multirow{2}{*}{ Dry Weight } & (Selfing & - & - & 80 \\
\hline & Crossing & - & - & 45 \\
\hline
\end{tabular}

\section{Self-FERTILtTy IN A RANGE OF POPULATIONS}

(i) Method

The relationship between the self-fertility of a population and other population characteristics was studied in a range of lead mine populations in order to gauge what factors could be determining the self-fertility in these populations.

Populations (10 plants each) of Agrostis tenuis were collected from 28 lead-contaminated areas in Cardiganshire, mid-Wales. The following population characteristics were noted:

1. Shortest distance between the population and edge of the mine, indicating the proximity of the tolerant populations to the non-tolerant.

2. Area of the mine from which the population came, again indicating the proximity of tolerant and non-tolerant populations. Area provides a more general estimate than distance.

3. Plant density. The density of the individuals in the area of collection was estimated as (1) isolated, (2) widely scattered, (3) sparse, (4) frequent, (5) close, (6) forming a tight sward.

4. Age of the mine. This was obtained from Jones (1922).

5. Flowering time. This was recorded on plants in the greenhouse (see McNeilly and Antonovics, 1967).

The plants were grown in standard greenhouse conditions for several months and tested for self-fertility.

\section{(ii) Results}

There were significant ( $\mathrm{P} \bumpeq 1$ per cent.) differences between populations in their self-fertility.

The multiple non-linear regression of self-fertility on four of the population features, namely distance, area, density and age was not significant, and selective regression techniques failed to pick out any particular relationship as significant. Individual regressions on the separate variables were therefore calculated. 


\section{(1) Distance and area}

The degree of self-fertility is plotted against the distance of the population from the edge of the mine, and against the square root of the area of the mine (fig. 5). The square root of the area is used so that the size of the mine can be considered in terms of "distance", i.e. on a linear scale. Data from populations collected in the previous year, 1964, is included: these mines were different from those collected in 1965.

Although the regressions are not significant, it is seen that self-fertility is generally greater where there is greatest gene flow, i.e. towards the edge of the mine or on smaller mines. Such trends are seen clearly in the case of self-fertility and area in both 1964 and 1965. Moreover, all the regressions are positive quadratic and negative linear, the approximate pattern of pollen distribution from a source.

\section{(2) Density}

The regression of self-fertility on plant-density is significant (fig. $5 d$ ), but it is difficult to see how a higher density would lead to a greater selffertility. However, plant density is itself related to distance from the edge of the mine $(\mathrm{P}<5$ per cent.) and some of the most dense populations come from the smallest mines. In other words, the relationship between selffertility and density might be a consequence of the relation of self-fertility with area and distance. Selective multiple regression showed that neither area/distance nor density gave significant independent contributions and therefore it is difficult to decide the causative factor.

(3) Age of mine

No clear relationship between self-fertility and age emerges. The regression is not significant and no trends are apparent.

\section{(4) Flowering time}

Flowering time does not appear to be related to self-fertility. There is no significant relationship either between mean self-fertility and mean flowering time of different populations or between self-fertility and flowering time of genotypes within populations.

\section{(iii) Conclusions}

The results presented here show that differences in self-fertility of Agrostis tenuis populations must be determined by a complex of factors. No one population characteristic emerges as of over-riding importance, but the distance of the tolerant populations from the non-tolerant seems to play some part.

\section{Computer simulation}

\section{(i) The model}

In order to define more precisely the factors which could determine self-fertility in a population subject to gene flow, a computer model of the situation was developed.

The model started with a single infinitely large random breeding population consisting of the genotypes $A A, A a$, and $a a$. Various factors were then allowed to operate. 

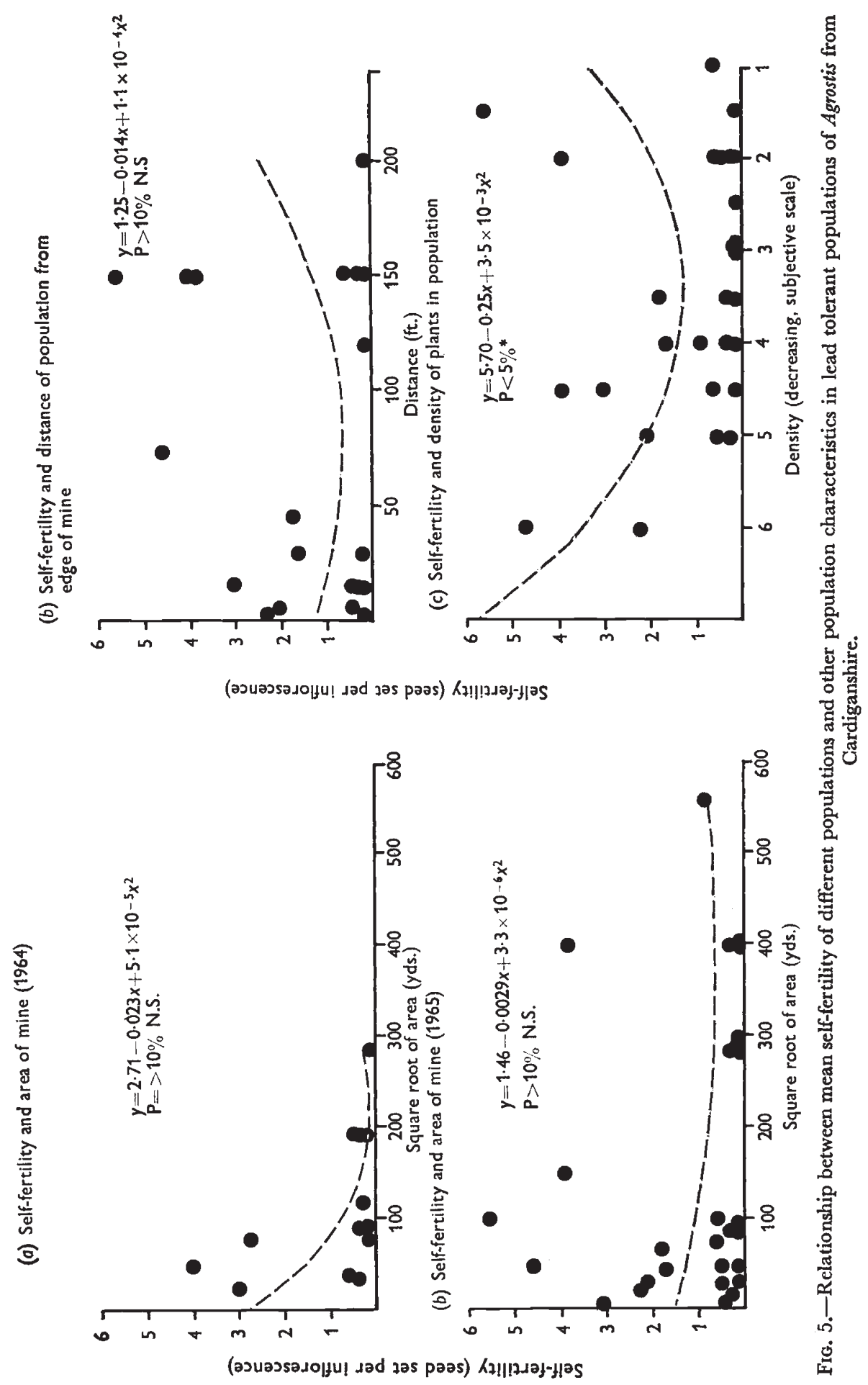


\section{Selection}

At each generation selection operated against the a genotype.

2. Gene flow

Gene flow was imposed by addition of a frequency, $g$, of incoming, $a a$, male genotypes. There are two kinds of gene flow, namely, pollen flow and seed flow, but in this model only pollen flow was considered. Here selection occurs after the incoming genotypes have mated with the remainder of the population (in seed flow selection occurs before mating).

\section{Self-fertility}

Self-fertility was imposed in two ways:

(a) Fully linked to the gene for tolerance. Self-fertility was imposed on the genotypes $A A$ and $A a$ to a degree $a_{1}$ and $a_{2}$. When the genotype $A A$ selfed to a degree $a_{1}$, then a proportion of $a_{1}$ of $A A$ females produced offspring without the involvement of males. The remainder of the females $\left(1-a_{1}\right)$ bred at random. The same applied to $A a$. In this model the genotype $a a$ was not given self-fertility because it was desired that the incoming genes should come from a non-self-fertile population.

(b) Unlinked to the gene for tolerance. Here a separate gene determining this character was introduced, unlinked to the other gene on which selection and gene flow was imposed. The gene for self-fertility was given the property of "incomplete penetrance". When present in a homozygous state a certain proportion, $a_{1}$, of the genotypes selfed. When present in the heterozygous state, a proportion $a_{2}$ selfed.

The recurrence equations for the linked and unlinked model were:

One gene model, selfing gene fully linked to favoured gene:

$$
\begin{aligned}
& A A^{\prime}=a_{1} u+\left(p-a_{1} u\right)[1-(p g+q)]+\frac{1}{4} a_{2} v[(q-p)-2 g p] \\
& A a^{\prime}=q+\left[\left(p-a_{1} u\right)-q\right](p g+q) \\
& a a^{\prime}=q(p g+q)-\frac{1}{4} a_{2} v[(q-p)+2 g p]
\end{aligned}
$$

where

$a_{1}=$ self-fertility of $A A$

$a_{2} \quad=$ self-fertility of $A a$

$g \quad=$ gene (pollen or seed) flow of $a a$

$p \quad=$ frequency of $A$

$q \quad=$ frequency of $a$

$u=$ frequency of $A A$

$v \quad=$ frequency of $A a$

$w=$ frequency of $a a$

$A A^{\prime}=$ frequency of $A A$ in the next generation

$A a^{\prime}=$ frequency of $A a$ in the next generation

$a a^{\prime}=$ frequency of $a a$ in the next generation

Two gene model, selfing gene unlinked to favoured gene:

$$
\begin{aligned}
& A A B B^{\prime}=h p^{2} u^{2}\left(b_{1} p+b_{2} q\right)+p u(u+0.5 v)\left(a_{1} p+0 \cdot 5 a_{2} q\right) \\
& A A B b^{\prime}=h p q u^{2}\left(b_{1} p+b_{2}+q\right)+p q u(u+0.5 v) a_{2} \\
& A A b b^{\prime}=h q^{2} u^{2}\left(b_{2} p+q\right)+0.5 p q u(u+0.5 v) a_{2}
\end{aligned}
$$




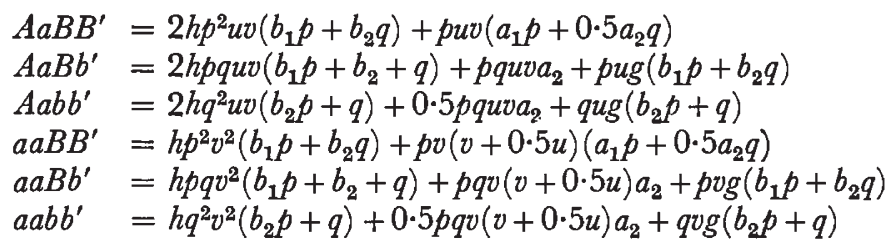

where

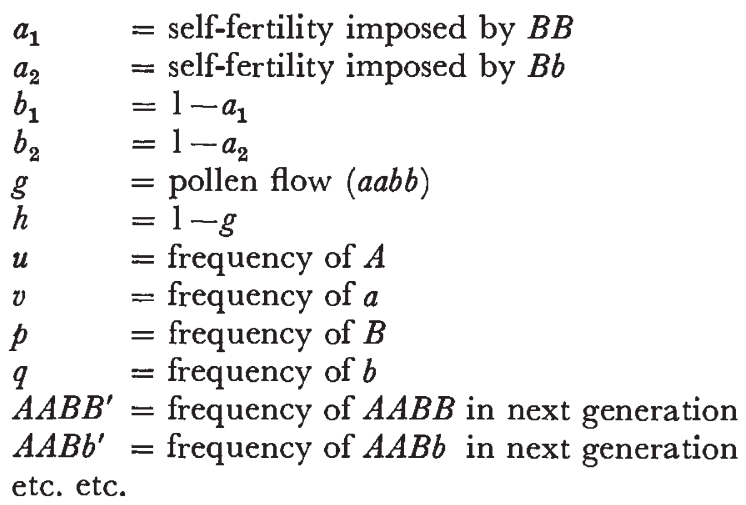

\section{Pollen-flow load}

Gene flow can have deleterious effects on a population by lowering frequencies of the adapted types. Gene-flow load is analagous to mutational load, producing an increased mortality amongst members of a population. This firstly limits rate of population increase for any population where the limiting factor to increase is the number of adapted individuals it can produce, and secondly, causes genetic changes in the population in the direction of reducing the gene-flow load.

Gene-flow load was calculated from the formula for genetic load on a population under selection:

$$
I=s(a a+(1-h) A a)
$$

where $I=$ genetic load, $s=$ selection coefficient, $h=$ degree of dominance, $A=$ favoured gene, $a=$ unfavoured gene. The genetic load due to selection is equivalent to the selection intensity (Van Valen, 1965).

The model for which a programme was developed can be summarised in the following way. Tolerance is determined by the gene $A$ and nontolerance by $a$. There is selection for tolerance on the mine, and non-tolerant genes are continually entering and tending to dilute the tolerance. The tolerant population carries genes for self-fertility which are themselves being diluted by the incoming genes. Selection, pollen flow, and self-fertility can vary and the self-fertility may be completely linked or completely unlinked to the genes for tolerance. The model is general for any habitat where there is selection and gene flow from a neighbouring source.

\section{(ii) Results}

The gene for selfing spreads through a population if no viability effects oppose it. This conclusion has also been reached by Crosby (1949). 
Moreover self-fertility aids the process of selection and assists gene fixation (table 3 ) since it helps to expose genes sheltered in a heterozygous state.

TABLE 3

Effect of linkage of gene for selfing to favoured gene on number of generations to fixation of the favoured gene in the population. (Selection coefficient $=1 \cdot 0$, dominance of favoured gene, no dominance of selfing gene, initial frequency of both genes $=0 \cdot 1$.)

\begin{tabular}{lrrrrrr} 
& \multicolumn{8}{c}{ Selfing } \\
Linkage & $>500$ & 0.2 & 0.4 & $0 \cdot 6$ & 0.8 & $1 \cdot 0$ \\
No linkage & $>500$ & 261 & 50 & 34 & 26 & 20 \\
0 & 136 & 93 & 70 & 56
\end{tabular}

Self-fertility reduces the pollen-flow load (fig. 6) when the self-fertility gene is linked to the tolerance gene. Selfing is more effective if the favoured gene is recessive and if the self-fertility gene is dominant. Thus if the favoured gene is completely dominant and the self-fertility gene completely recessive, then self-fertility has no effect on the pollen-flow load. Selfing is more effective if the pollen flow is greater and if the selection pressure is greater.
Favoured gene
Favoured gene
no dominance dominant

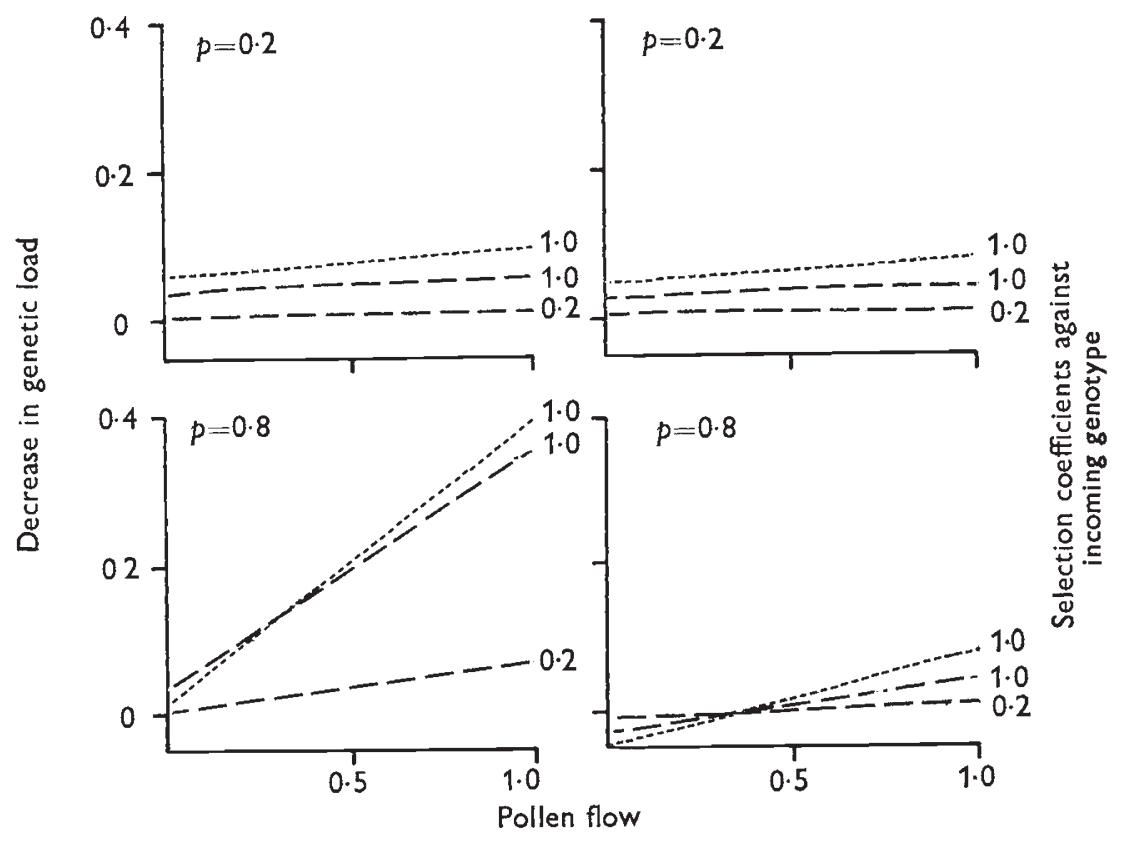

Selfing gene no dominance Selfing gene dominant

Frg. 6.-Decrease in genetic load due to complete selfing of the favoured type, with different amounts of selection and pollen flow, and at various (not necessarily equilibrium) gene frequencies, $p$, of the favoured gene. Selfing gene completely linked to favoured gene. 
Moreover self-fertility aids the process of selection and assists gene fixation (table 3 ) since it helps to expose genes sheltered in a heterozygous state.

TABLE 3

Effect of linkage of gene for selfing to favoured gene on number of generations to fixation of the favoured gene in the population. (Selection coefficient $=1 \cdot 0$, dominance of favoured gene, no dominance of selfing gene, initial frequency of both genes $=0 \cdot 1$.)

\begin{tabular}{lrrrrrr} 
& \multicolumn{8}{c}{ Selfing } \\
Linkage & $>500$ & 0.2 & 0.4 & $0 \cdot 6$ & 0.8 & $1 \cdot 0$ \\
No linkage & $>500$ & 261 & 50 & 34 & 26 & 20 \\
0 & 136 & 93 & 70 & 56
\end{tabular}

Self-fertility reduces the pollen-flow load (fig. 6) when the self-fertility gene is linked to the tolerance gene. Selfing is more effective if the favoured gene is recessive and if the self-fertility gene is dominant. Thus if the favoured gene is completely dominant and the self-fertility gene completely recessive, then self-fertility has no effect on the pollen-flow load. Selfing is more effective if the pollen flow is greater and if the selection pressure is greater.
Favoured gene
Favoured gene
no dominance dominant

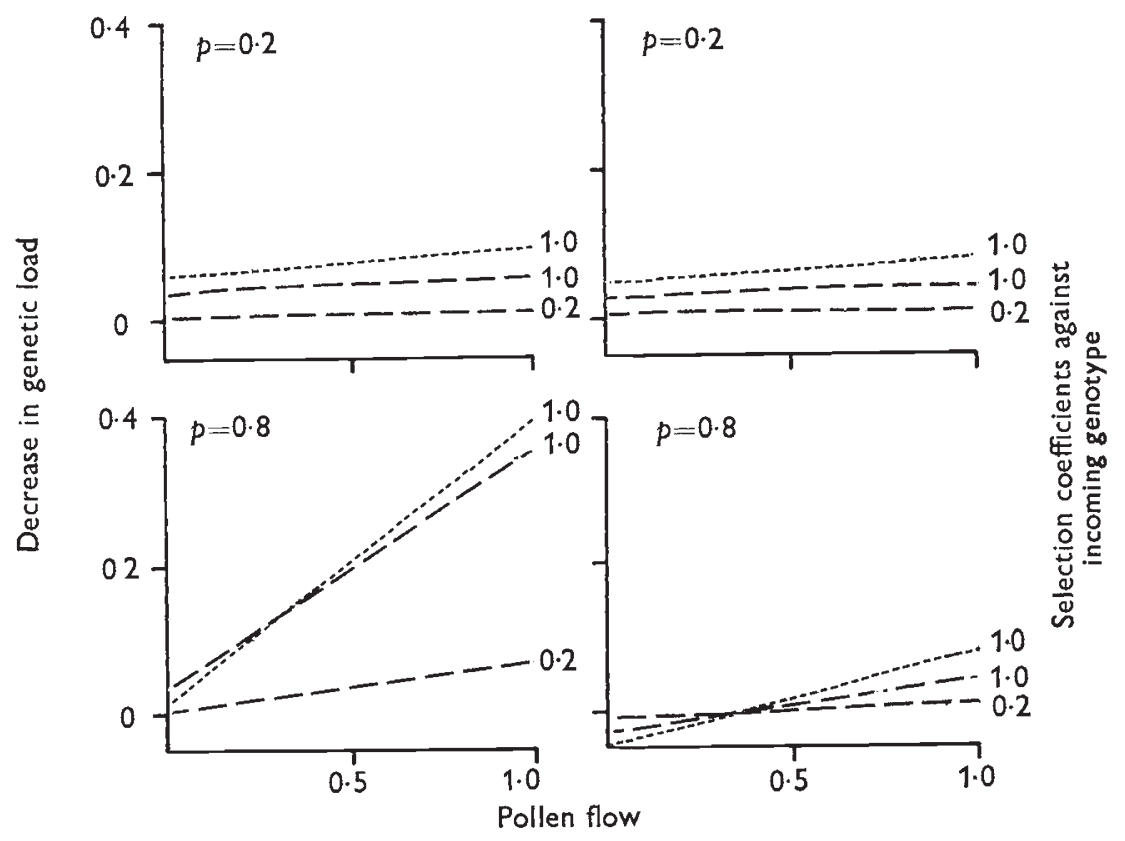

Selfing gene no dominance Selfing gene dominant

Frg. 6.-Decrease in genetic load due to complete selfing of the favoured type, with different amounts of selection and pollen flow, and at various (not necessarily equilibrium) gene frequencies, $p$, of the favoured gene. Selfing gene completely linked to favoured gene. 

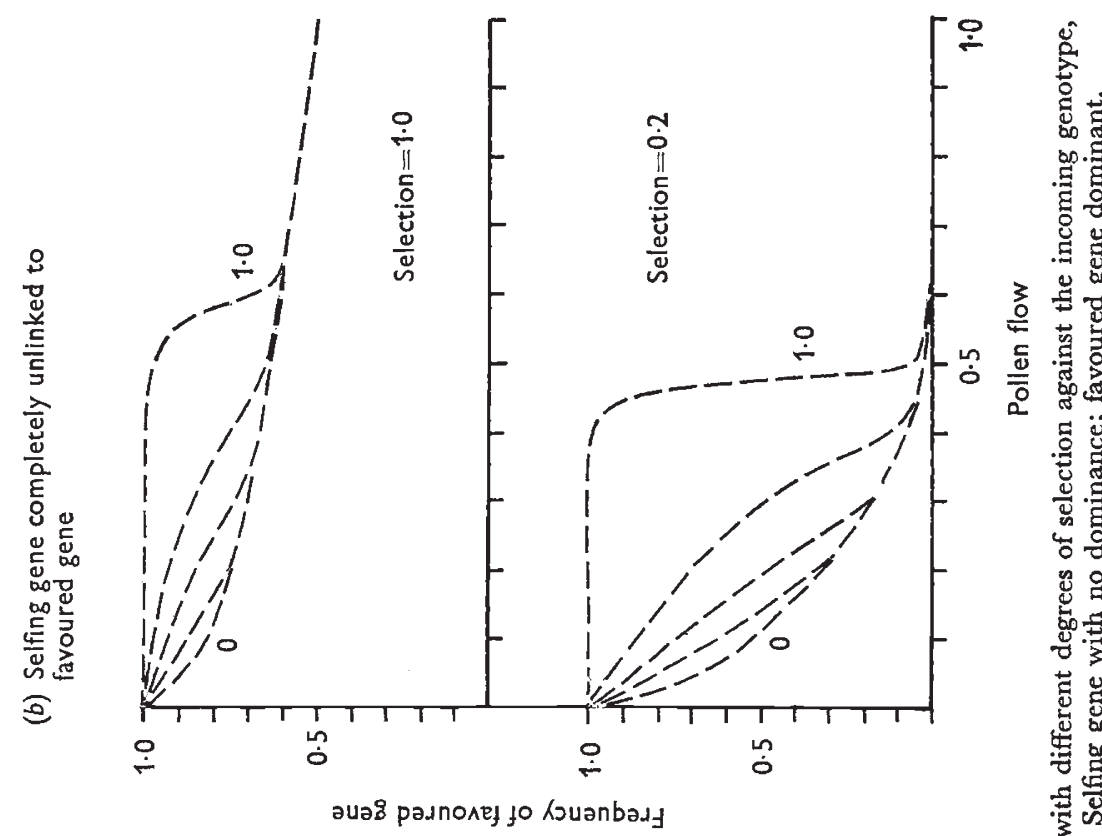

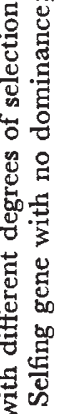

혈

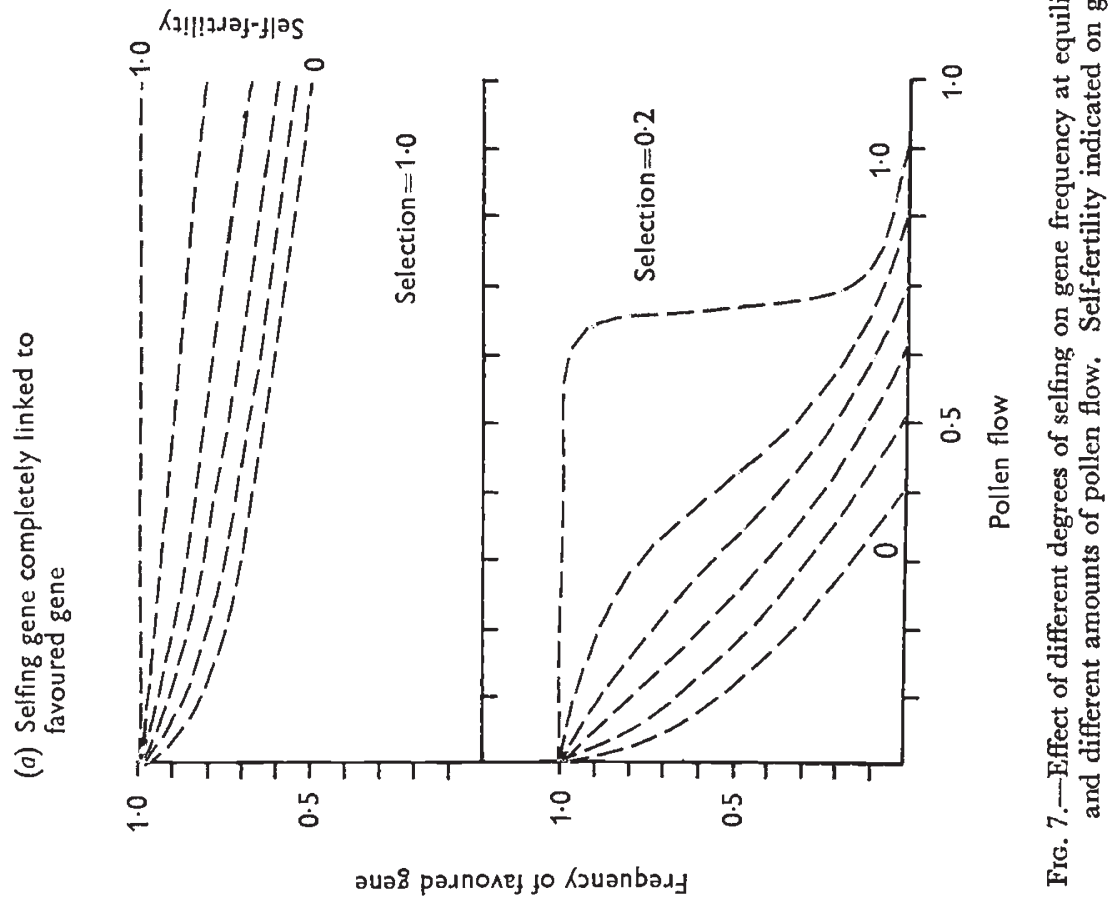


The effects of selfing on gene frequency confirm and extend the results from pollen-flow load studies. It is seen (fig. 7) that selfing considerably increases the frequency of the selected gene. Selfing is less effective at counteracting pollen flow if it is unlinked to the favoured gene (fig. 8), and under high pollen flow the gene for selfing is swamped by the incoming genes.

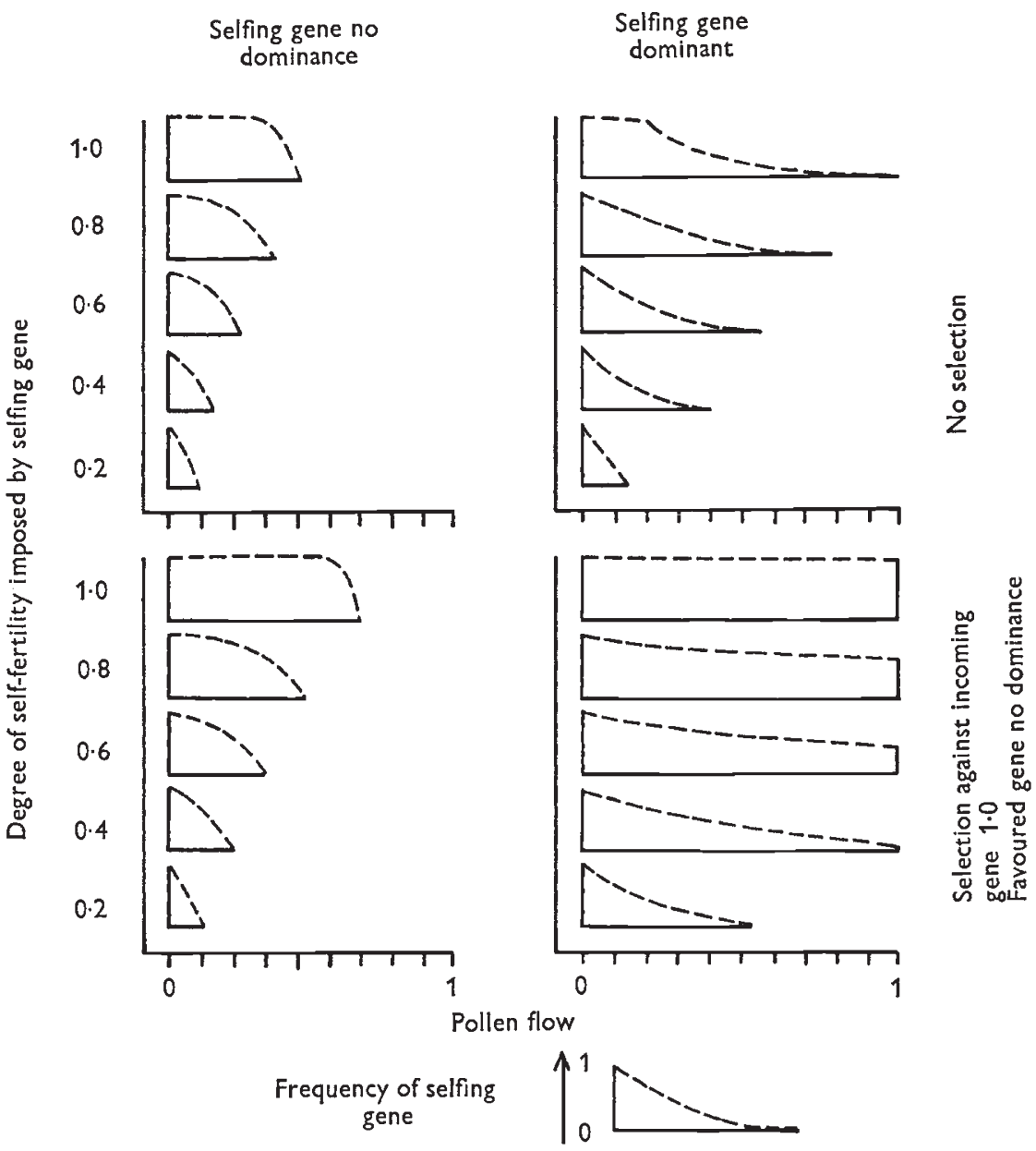

FIG. 8.-Frequency of selfing gene at equilibrium with no selection and with complete selection against the incoming gene, and with various degrees of self-fertility and pollen flow. Selfing gene completely unlinked to favoured gene.

An unlinked gene for selfing might be expected to spread through a population under conditions of gene flow more than it would spread of its own accord. The results (fig. 8) show that if the gene for selfing shows no dominance, then the selection for the favoured gene does not increase the final frequency of the selfing gene compared with the frequency when there is no selection, although it does hasten the rate at which equilibrium is reached. But when the selfing gene is dominant its spread is considerably more and again the spread is greater if the favoured gene shows no dominance. 


\section{(iii) Conclusions}

Given that the population does not suffer from inbreeding depression, the gene for selfing will spread through a population of its own accord. If there is selection, but no gene flow, the rate of spread of the selfing gene is increased. If there is gene flow, then the selfing gene will increase more rapidly than under any other circumstance.

Under conditions of gene flow many factors other than gene flow itself determine the fate of a gene for selfing. These factors, like intensity of selection, degree of dominance of the genes, and linkage can be used to predict circumstances under which selfing would be at a premium.

\section{Discussion}

Differences in the self-fertility of populations have rarely been reported. The present example is therefore of considerable interest. The mean difference in self-fertility between mine and pasture populations may not appear to be very large, but tolerant populations do contain individuals with a very high self-fertility, often with values approaching those of normal cross-fertility. The difference is also remarkable in view of the short distance over which it occurs.

The evidence of such a difference between two populations immediately raises the question as to its origin. Where differences have been found in the past they have been interpreted in terms of establishment after longdistance transport (Bannister, 196 ; Moore and Lewis, 1962), absence of pollinators (Lloyd, 1965) or in terms of breakdown of self-incompatibility and inherent spread of self-fertility genes (Crosby, 1949). All these explanations, however, are inadequate in explaining the situation in mine populations, since the only trend to emerge from a study of different populations of varying degrees of self-fertility is a relationship between degree of selffertility and the proximity of a tolerant population to a non-tolerant one.

This relationship implies that selfing is at a premium where there is a considerable amount of gene-flow and that it has evolved as an isolating mechanism. No evidence is available as to the effectiveness of self-fertility as an isolating mechanism: no marker genes are available and self-fertility in the presence of other genotypes cannot be tested. The gain in the number of tolerant seeds that result from selfing may seem small from the data presented here, but two factors must be remembered.

Firstly, self-fertility is measured at Drws-y-Coed and Trelogan at a stage when evolution has already progressed for some time. In the earlier stages of colonisation the density of plants on the mine was far lower than it is now and the effects of gene flow would have been more serious. A more elaborate computer model (to be described in a later paper) illustrates the importance of self-fertility in the early stages of colonisation (fig. 9). At present the effective gene flow must be much lower and since there is a certain amount of inbreeding depression, the populations may well have largely reverted to a fairly high degree of cross-fertility.

Secondly, it has been demonstrated in the previous paper in this series (McNeilly and Antonovics, 1967) that other isolating mechanisms are also operative and therefore differences in self-fertility may not be very extreme.

It is evident that the relationship between self-fertility and gene flow is not clear cut. The situation must vary from population to population with 
no one factor determining the breeding system in every instance. For example some populations of high fertility are far from mine boundaries or have plants at a very low density: here other factors may be determinant.

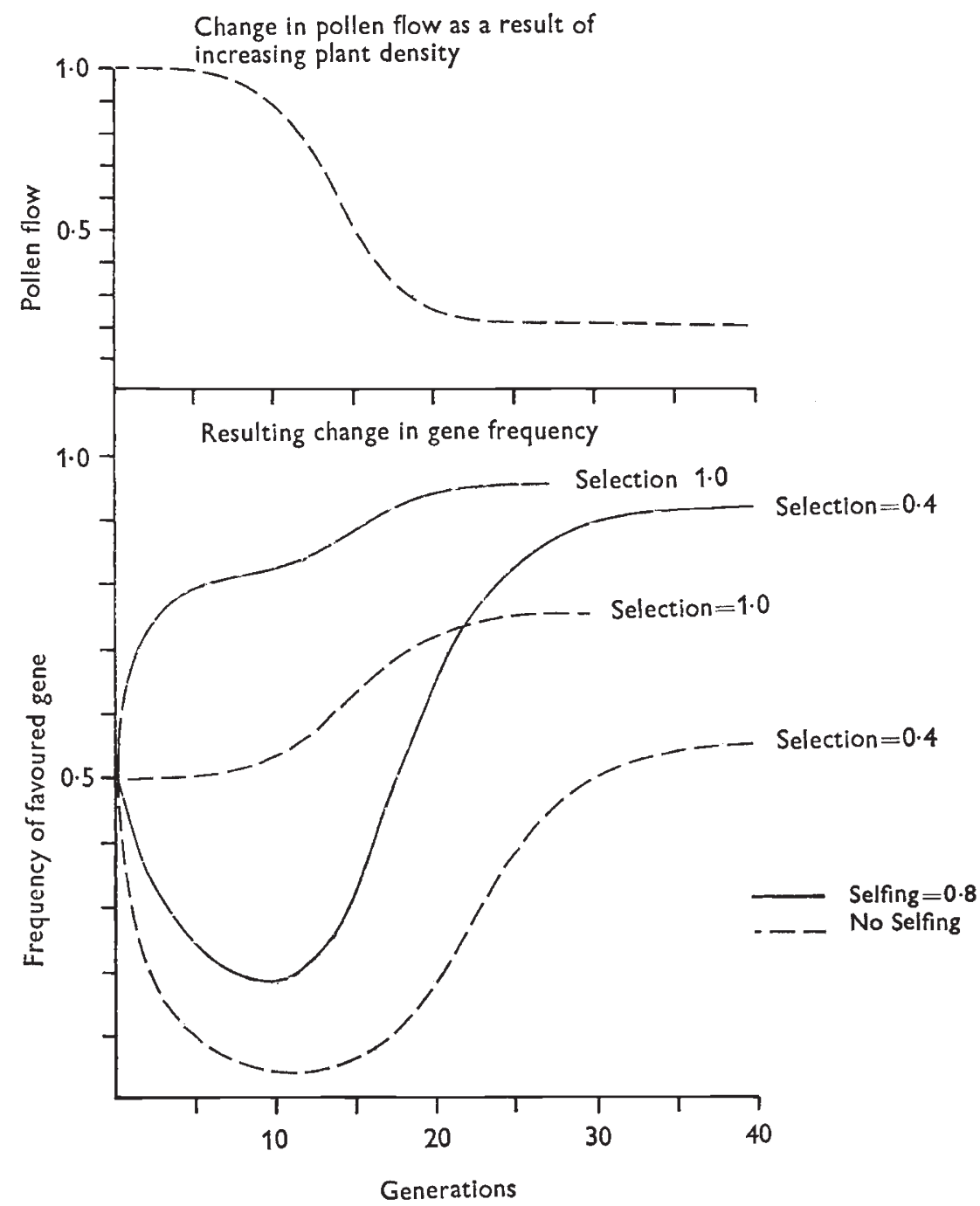

FIG. 9.-Effect of self-fertility on gene frequency under conditions of changing pollen flow. Selfing gene no dominance, favoured gene dominant.

The computer simulation of the evolution of self-fertility in the face of gene flow leads to certain predictions which it should be possible to verify. One of the main predictions is that the genes for self-fertility should be linked to the tolerance genes. If the self-fertility is plotted against the degree of tolerance in the mine population of Anthoxanthum, a highly suggestive relationship is obtained (fig. 10). These results could perhaps be alternatively interpreted in terms of a pleiotropic effect of the tolerance mechanism but this is not only difficult to envisage in terms of physiological 
mechanism of tolerance (Turner and Gregory, 1967), but it is unlikely to happen in the case of tolerance to different metals, and in different species on contrasting mines. Certainly the computer simulation does not argue against the hypothesis that gene flow can be a determining factor.

In the argument for the evolution of selfing by selection, inbreeding depression is a problem. A mine population is likely to establish from "sib-matings" between a few founder individuals. Such inbreeding should lead to a readjustment of the gene complexes to adapt them to tolerate the depressive effects of inbreeding. Such readjustment has been shown to be

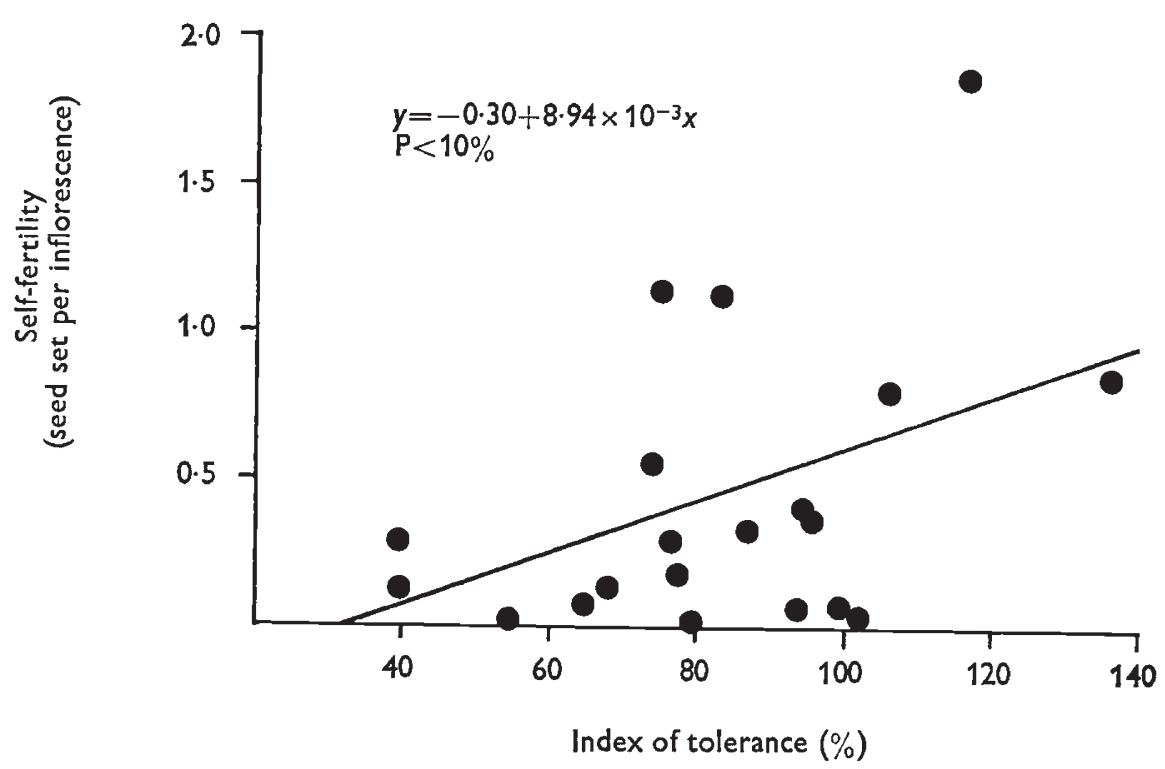

Frg. 10.-Relationship between tolerance and self-fertility of genotypes in tolerant Anthoxanthum from Trelogan.

possible in other species (Wexelsen, 1952; Rowlands, 1961; Breese, 1964). The inbreeding depression in Anthoxanthum may argue against this, but it must be remembered that, in tolerant populations at least, this depression only manifests itself under competitive conditions.

The evolution of self-fertility must depend on populations being forced through a severe bottleneck. This is probably why selfing does not occur off the mine in pasture populations. Firstly, these populations have never been subjected to inbreeding among a few colonisers. Secondly, selfing will not be strongly favoured since selection pressure against the incoming tolerant gene is very small (McNeilly, 1967). In other words, mine populations have been pushed against a bottleneck, whereas pasture populations have not. The few highly self-fertile individuals in mine populations seem to have already passed through this bottleneck and to constitute but one step before self-fertility becomes fully established in an entire population.

The situation at the boundaries of metal mines may help to explain the present occurrence of inbreeding in other species, since the development of heavy metal tolerance is a model for any species entering and colonising a new adaptive zone. Such small-scale evolution may be the beginning of large-scale differences. 


\section{Summary}

1. Populations of Agrostis tenuis and Anthoxanthum odoratum tolerant to heavy metals were shown to have a greater self-fertility than adjacent non-tolerant populations.

2. The degree of self-fertility was inherited.

3. Seed produced by self-fertilisation was competitively inferior to seed produced by crossing.

4. There were significant differences between the self-fertility of different mine populations. These differences could be related in part to the proximity of these populations to non-tolerant populations.

5. Self-fertility was therefore interpreted as a barrier to gene flow.

6. Computer simulation of the process showed that self-fertility will reduce the pollen-flow load on a population, and that genes for self-fertility would spread through a population in the face of gene flow. Linkage of the gene for self-fertility to the gene for tolerance, high selection pressures, high frequency of the favoured gene, dominance of the selfing gene and recessiveness of the favoured gene, increase the frequency of the gene for selffertility.

7. This situation is a model which could explain the occurrence of inbreeding in other species.

Acknowledgments. - I wish to thank Dr A. D. Bradshaw for his encouragement and enthusiasm during this work and the members of the Computing Laboratory at the University College of North Wales, Bangor, for their friendly assistance. I would also like to acknowledge the tenure of a University of Wales I.C.I. Research Fellowship during part of this work.

\section{REFERENCES}

ALlARD, R. W. 1965. Genetic systems associated with colonising ability in predominantly self-pollinated species. In Baker, H. G., and Stebbins, G. L. (Eds.), The Genetics of Colonising Species. Academic Press, 49-76.

Antonovics, J. 1966. The genetics and evolution of differences between closely adjacent plant populations with special reference to heavy metal tolerance. Ph.D. Thesis, University of Wales. BAKER, H. G. 1953. Race formation and reproductive method in flowering plants. Symp. Soc. exp. Biol., 7, 114-143.

BAKER, H. G. 1955. Self-compatibility and establishment after long-distance dispersal. Evolution, 9, 347-348.

BAKER, H. G. 1959. Reproductive methods as factors in speciation in flowering plants. Cold Spring Harb. Symp. quant. Biol., 24, 177-191.

BANNister, м. H. 1965. Variation in the breeding system of Pinus radiata. In Baker, H. G., and Stebbins, G. L. (Eds.), The Genetics of Colonising Species. Academic Press, 353-374. BEDDows, A. R. 1931. Seed setting and flowering in various grasses. Rep. Welsh Pl. Breed. Stn. Series H. Seasons 192l-1930, 12, 5-99.

BREESE, E. L. 1956. The genetical consequences of assortative mating. Heredity, 10, 232-243. BREESE, E. L. 1959. Selection for differing degrees of out-breeding in Nicotiana rustica. Ann. Bot. N.S., 23, 331-344.

Grosby, J. 1959. Selection of an unfavourable gene-complex. Evolution, 3, 212-230.

DAvies, W. E., AND YounG, N. R. 1966. Self-fertility in Trifolium fragiferum. Heredity, 21, 615-624.

DE WIT, c. T., 1960. On Competition. Versl. Landbowk. Onderz. Ned., 66 (8), 1-82.

IMAM, A. G., AND ALLARD, R. W. 1965. Population studies in predominantly self-pollinated species. VI. Genetic variability between and within natural populations of wild oats, Avena fatua L., from differing habitats in California. Genetics, 51, $49-62$.

JENKIN, T. J. 1931. Self-fertility in perennial ryegrass (Lolium perenne L.). Rep. Welsh Pl. Breed. Stn. Series H. Seasons 1921-1930, 12, 100-125.

Jones, o. T. 1922. Lead and zinc. The mining district of North Cardiganshire and West Montgomeryshire. Mem. Geol. Surv. spec. Rep. Min. Resourc. Gt. Br., 20. 
JULEN, G. 1948. Inbreeding in herbage plants. In Akerman, A., Tedin, O., and Froier, K. (Eds.), Svalof 1886-1946. History and Present Problems. 211-216.

LLOYD, D. G. 1965. Evolution of self-compatibility and racial differentiation in Leavenworthia (Cruciferae). Contr. Gray Herb. Harv., 195, 1-134.

MCNEILly, T. 1967. Evolution in closely adjacent plant populations. III. Agrostis tenuis on a small copper mine. Heredity, 23, 99-108.

MCNEILLY, T., AND ANToNovics, J. 1967. Evolution in closely adjacent plant populations. IV. Barriers to gene flow. Heredity, 23, 205-218.

MOORE, D. M., AND LEWIs, H. 1965. The evolution of self-pollination in Clarkia xantiana. Evolution, 19, 104-114.

RICK, C. M. 1950. Pollination relations of Lycopersicum esculentum in native and foreign regions. Evolution, 4, 110-122.

Rowlands, D. G. 1960. Fertility studies in the field bean (Vicia faba L.). I. Cross and self-fertility. Heredity, 15, 161-173.

Rowlands, D. G. 1961. Fertility studies in the field bean (Vica faba L.). II. Inbreeding. Heredity, 16, 497-508.

SEAton, A. P. C., AND ANTonovics, J. 1967. Population interrelationships. I. Evolution in mixtures of Drosophila mutants. Heredity, 22, 19-33.

STEBBiNs, G. L. 1957. Self-fertilisation and population variability in the higher plants. Am. Nat., 91, 337-354.

тномаs, H. L. 1955. Inbreeding and selection of self-fertilised lines of Red Clover, Trifolium pratense. Agron. 7., 47, 487-489.

THOMPSON, K. F., AND TAYLOR, J. P. 1966. The breakdown of self-incompatibility in cultivars of Brassica oleracea. Heredity, 21, 637-648.

TURNER, R. G., AND GREGORY, R. P. G. 1967. The use of radioisotopes to investigate heavy metal tolerance in plants. In Isotopes in Plant Nutrition and Physiology, I.A.E.A. Symposium, Vienna. 493-509.

VAN VALEN, $\mathbf{L}$. 1965. Selection in natural populations. III. Measurement and estimation. Evolution, 19, 514-528.

WEXELSEN, H. 1962. The use of inbreeding in forage crops. 6th Int. Grass. Congr., 1, 299-305. 